\title{
STRATEGI PEMASARAN STP (SEGMENTING, TARGETING, POSITIONING) PADA LARISSA AESTHETIC CENTER CABANG JEMBER
}

\author{
Fitria Rismawati $^{1}$, Sri Wahyuni ${ }^{1}$, Joko Widodo ${ }^{1}$ \\ ${ }^{1}$ Pendidikan Ekonomi, Fakultas Keguruan dan Ilmu Pendidikan, Universitas Jember \\ Jln. Kalimantan 37, Jember 68121 \\ E-mail: fitriarismawati18@gmail.com
}

\begin{abstract}
Abstrak
Penelitian ini bertujuan untuk mendeskripsikan segmenting, targeting dan positioning dalam pemasaran Larissa Aesthetic Center cabang Jember. Penelitian ini merupakan penelitian deskriptif dengan pendekatan kualitatif. Subyek dan informan penelitian yaitu Branch Manager, Customer Service dan Pelanggan Larissa Aesthetic Center cabang Jember. Metode pengumpulan data yang digunakan adalah metode wawancara, observasi dan dokumen. Langkah-langkah analisis data yang digunakan antara lain reduksi data, penyajian data dan penarikan kesimpulan. Berdasarkan penelitian yang dilakukan, peneliti menyimpulkan bahwa strategi segmenting yang dilakukan Larissa Aesthetic Center cabang Jember yaitu didasarkan pada segmentasi geografis dan demografis. Segmentasi geografis, wilayah yang dituju yaitu wilayah Tapal Kuda, meliputi; Jember, Bondowoso, dan Lumajang. Segmentasi demografisnya meliputi PNS, karyawan swasta, mahasiswa, ibu-ibu muda dengan usia 17-60 tahun, melayani perempuan dan laki-laki yang berpendapatan sedang dan menengah kebawah Targeting, target pasar yang utama yaitu mahasiswa, ibu-ibu muda dan karyawan swasta. Strategi penetapan sasaran yang digunakan yaitu strategi penetapan sasaran majemuk yaitu menciptakan berbagai jenis perawatan dan produk yang dapat memenuhi kebutuhan konsumen secara luas. positioning yang dilakukan Larissa Aesthetic Center cabang Jember yaitu menciptakan citra merek dan slogan dibenak konsumen, bahwa produk dan jasa yang ditawarkan memiliki manfaat kesehatan karena produk dan perawatan menggunakan bahan alami yang mudah diterima semua jenis kulit dan harga yang ditawarkan lebih terjangkau dibanding dengan yang lain.
\end{abstract}

Kata Kunci: Segmenting, Targeting, Positioning

\section{PENDAHULUAN}

Seiring dengan perkembangan yang pesat mengakibatkan para pelaku bisnis lebih tanggap dengan perubahan yang terjadi sehingga menimbulkan persaingan yang kuat, terutama dalam bidang pemasaran. Adanya persaingan yang sangat kuat mengakibatkan strategi yang dilakukan pada periode sebelumnya belum tentu berhasil jika diterapkan pada periode saat ini atau periode yang akan datang. Perusahaan dituntut melihat ke depan dan mengembangkan strategy yang diterapkan untuk disesuaikan dengan perubahan yang terjadi saat ini yang bertujuan untuk mempertahankan dan memperluas pasar sasarannya.

Saat ini banyak berdirinya klinik kecantikan yang menawarkan berbagai jasa dan produk kecantikan, karena di dorong oleh semakin banyaknya kebutuhan dan keinginan masyarakat dalam hal perawatan kecantikan. Beberapa klinik kecantikan terbaik di Indonesia yang membuka cabang dikota Jember adalah London Beauty Center, Larissa Aesthetic Center, Natasha Skincare, dan Erha Clinic. Larissa Aesthetic Center adalah klinik kecantikan yang berusaha untuk memenuhi kebutuhan konsumen mengenai perawatan kecantikan dengan mengusung konsep "Natural Ingredient With Technology”. produk dan perawatan jasa yang ditawarkan Larissa Aesthetic Center menggunakan bahan alami, yang dalam pemasarannya memiliki tantangan tersendiri untuk memperkenalkan perawatan dan produknya kepada masyarakat, karena bahan alami tersebut membutuhkan waktu yang relatif lama dibanding dengan para pesaingnya dalam menghasilkan hasil yang maksimal. Oleh karena itu Larissa Aesthetic Center cabang Jember mengembangkan keunggulan bersaing dengan melakukan segmenting, penargetan pasar (targeting) dan memposisikan (positioning) perusahaan dengan tepat dibenak konsumen. Tjiptono (2007:211) mengemukakan bahwa tujuan pokok strategi STP adalah memposisikan suatu merk di benak konsumen, sehingga merk tersebut memiliki keunggulan 
kompetitif yang berkesinambungan. Sebuah produk akan memiliki keunggulan kompetitif jika produk tersebut menawarkan atribut yang determinan, bernilai penting dan unik oleh pelanggan.

Perusahaan menyadari bahwa tidak semua produksi yang ditawarkan dapat menarik semua konsumen, konsumen sangat banyak, menyebar luas dan kebutuhan \& keinginan konumen selalu berubah-ubah. Kondisi inilah yang mendorong perusahaan dapat saling bersaing untuk menempati posisi yang baik dalam melayani semua konsumen. Berdasarkan penjelasan diatas, peneliti melakukan penelitian yang bertujuan untuk mendeskripsikan segmenting, targeting, positioning dalam pemasaran Larissa Aesthetic Center cabang Jember.

\section{METODE}

Penelitian ini merupakan jenis penelitian deskriptif dan menggunakan pendekatan kualitatif yang bertujuan untuk mendeskripsikan dan menjabarkan segmenting, targeting, positioning dalam pemasaran yang dilakukan oleh Larissa Aesthetic Center cabang Jember. Penentuan lokasi penelitian menggunakan metode purposive area. Subjek dalam penelitian ini adalah Branch Manager sebagai informan utama yang benar-benar menguasai dan memahami permasalahan yang diteliti, sedangkan informan tambahan adalah customer service dan konsumen. Metode pengumpulan data yaitu menggunakan metode wawancara, metode observasi dan metode dokumen. Langkah- langkah analisis data yang digunakan yaitu reduksi data, penyajian data dan penarikan kesimpulan.

\section{HASIL DAN PEMBAHASAN \\ Hasil Penelitian}

Berdasarkan penelitian yang dilakukan, Larissa Aesthetic Center merupakan klinik kecantikan yang berdiri pada tanggal 11 Juni 1984, oleh R. Ngt. Poedji Lirnawati. Konsep yang digunakan dikenal dengan 'back to nature' yaitu perawatan yang menggunakan bahan alami seperti sayuran, buah, umbi, batang dan akar yang disinergikan melalui teknologi modern dan dengan harga yang terjangkau. Selain menawarkan jasa perawatan kulit dan rambut juga menghadiran produk kosmetik sendiri dengan bahan alami yang aman dan sudah bersertifikat CPKB (Cara Pembuatan Kosmetik yang Baik) dari BPOM RI tahun 2006. Larissa Aesthetic Center cabang Jember merupakan cabang ke 19 dari 36 cabang yang bertempat di Jalan S. Parman No. 42-46, Lingkungan Sadengan, Kebonsari, Sumbersari, Jember. Hasil penelitian yang diperoleh bahwa Larissa Aesthetic Center cabang Jember dalam memasarkan produk dan jasanya yaitu melakukan strategi STP. Hasil identifikasi dari penelitian tentang STP adalah sebagai berikut

\section{Segmentasi pasar (Segmenting) yang dilakukan Larissa Aesthetic Center cabang Jember}

Segmentasi pasar dilakukan dengan tujuan untuk mengetahui pasar mana yang potensial untuk dijadikan target pasar sehingga dapat meningkatkan jumlah kunjungan. Strategi segmenting yang dilakukan Larissa Aesthetic Center cabang Jember yaitu di dasarkan pada segmentasi geografis dan demografis. Segmentasi geografis, dalam pemasarannya, produk dan jasa yang ditawarkan tidak hanya menyebar di wilayah Jember saja melainkan menyebar di wilayah Tapal Kuda sebagai wilayah yang potensial dalam membidik pasar sasaran untuk memenuhi keinginan dan kebutuhan konsumen. Hal ini dibuktikan dengan semakin canggihnya teknologi saat ini, Larissa Aesthetic Center cabang Jember memanfaatkan peluang yang ada dengan melakukan promosi menggunakan Instagram dan Facebook yang mudah dikenal masyarakat, selain itu juga adanya website yang memberikan kemudahan untuk mendapatkan informasi tentang produk, dan treatment yang ditawarkan. Segmentasi demografisnya meliputi ; PNS, karyawan swasta, mahasiswa dan ibu-ibu muda, semua itu dipilih karena lokasi Larissa Aesthetic Center cabang Jember berada di pusat kota, tepatnya di kecamatan Sumbersari. Sumbersari merupakan salah satu kecamatan di Jember yang memiliki tingkat kepadatan yang tinggi karena banyak berdirinya perkantoran, fasilitas pendidikan dan fasilitas perdagangan. Usia yang dituju yaitu usia 17-60 tahun karena berkaitan dengan kebutuhan, keinginan dan permasalahan kulit. Larissa Aesthetic Center cabang Jember melayani konsumen perempuan dan laki-laki. Produk dan jasa Larissa Aesthetic Center cabang Jember ditujukan untuk kalangan berpendapatan menengah dan berpendapatan menengah kebawah.

Targeting yang dilakukan Larissa Aesthetic Center cabang Jember 
Strategi yang dilakukan Larissa Aesthetic Center cabang Jember dalam memutuskan target pasar adalah dengan memperhatikan ukuran atau besarnya segmen yang telah dipilih. Segmen pasar yang dipilih untuk dijadikan target pasar adalah mahasiswa, ibu-ibu muda dan karyawan swasta, karena target utama tersebut dianggap memiliki tingkat pertumbuhan penjualan yang tinggi karena harga yang ditawarkan masih mudah untuk dijangkau. Mahasiswa dan ibu-ibu muda saat ini tentu memiliki keinginan dalam menjaga penampilan tubuh dan wajahnya untuk terlihat cantik di pergaulan maupun di lingkungan masyarakat dan

Perusahaan saat ini banyak yang menuntut karyawannnya untuk memperhatikan penampilan saat bekerja, misalnya penampilan rambut dan wajah. Strategi penetapan pasar sasaran Larissa Aesthetic Center cabang Jember menggunakan strategi penetapan majemuk ( Multisegment Targeting Strategy) yaitu perusahaan menganut sistem pemasaran majemuk, dimana perusahaan menciptakan beberapa jenis perawatan dan produk berbeda dalam memenuhi kebutuhan seluruh konsumen.

\section{Positioning yang dilakukan Larissa Aesthetic Center cabang Jember}

Positioning adalah cara yang dilakukan perusahaan dalam merancang citra produk untuk memperoleh posisi yang baik di benak konsumen. Larissa Aesthetic Center cabang jember dalam melakukan positioning mengunakan beberapa variabel antara lain:

a. Atribut Merek

Merek Larissa Aesthetic Center sudah dikenal diberbagai kalangan sejak tahun 1984, Larisssa sudah mempunyai banyak pelanggan yang tersebar di 36 cabang termasuk Jember.

Atribut merek ditanamkan kepada konsumen melalui slogan dan citra merek yang diterapkan, dalam menyambut konsumen, Larissa Aesthetic Center cabang Jember selalu menggunakan salam sebagai ciri khas Larissa yang berbunyi " salam kulit sehat Larissa". Salam tersebut bertujuan untuk memberikan penghormatan kepada konsumen, selain itu salam tersebut menjelaskan mengenai ciri khas bahwa klinik kecantikan tersebut menawarkan perawatan dan produk yang bahan utamanya menggunakan bahan alami yang sehat untuk kulit. Selain salam, dalam memberikan pelayanan Larissa Aesthetic Center cabang Jember mengacu pada kebijakan mutu yang berasal dari pusat. Kebijakan mutu dilakukan dengan meningkatkan kualitas produk yang dimiliki dan kualitas karyawan untuk memuaskan pelanggan. Citra merek yang ditanamkan kepada konsumen yaitu dengan menyebutkan manfaat dari penggunaan produk dan perawatan dari Larissa. untuk menghasilkan hasil yang maksimal, hasil yang diperoleh tidak terlihat secara langsung tetapi perlu adanya tahapan- tahapan karena bahan berasal dari bahan alami yang cenderung tidak memiliki efek samping. Bahan alami akan terasa manfaatnya apabila digunakan secara rutin dan teratur untuk mempertahankan kondisi kulit yang sehat.

b. Harga dan kulaitas

Salah satu keunggulan Larissa Aesthetic Center cabang Jember yaitu harga lebih terjangkau dibanding dengan para pesaingnya, karena bahan yang digunakan menggunakan bahan alami. Bahan alami tersebut dalam perolehannya mudah didapatkan di Indonesia dan harganya relatif murah. Meskipun harganya murah, Larissa Aesthetic Center cabang Jember menjamin tingkat keamanan dan kesehatan kulit dengan memberikan asuransi kecelakaan diri kepada para pelanggannya. Harga yang ditawarkan sudah dalam rangkaian perawatan, perawatan yang bisa dikatakan murah yaitu perawatan organik dengan harga Rp. 75.000 sampai HTD atau tindakan dokter dengan harga Rp. 350.000, semua itu sudah termasuk konsultasi dokter, rangkaian perawatan seperti cleasing, peeling, massage dan tindakan dokter (jika hitec dokter) steam, ekstraksi, high frequence dan masker. Harga produk mulai dari harga

Rp. 16.000- 100.000. Semua harga menyesuaikan dengan kebutuhan konsumen dan tidak adanya paksaan untuk melakukan transksi perawatan maupun pembilan produk.

c. Pesaing

Menjamurnya klinik kecantikan yang berada di Jember mengakibatkan persaingan yang kuat, untuk dapat bersaing dengan para pesaingnya, pelayanan merupakan hal utama yang diperhatikan dalam menghadapi konsumen. pelayanan yang diberikan perusahaan berbeda dengan yang lain karena produk yang digunakan merupakan produk individu. Larissa Aesthetic Center cabang Jember berusaha peduli terhadap permasalahan dan produk atau perawatan yang di inginkan oleh konsumen. Konsumen tidak dipaksa untuk menggunakan produk tetapi konsumen disarankan sesuai dengan konsultasi dokter 
dan permasalahan yang dialami. Konsep layanan yang diberikan mengedepankan tata cara berbicara yang baik, sopan santun dan menarik konsumen untuk datang kembali dengan menginformasikan promo-promo yang berlaku. Upaya tersebut telah memenuhi standar Internasional yang mengatur tentang sistem manajemen mutu. Penerapan standar tersebut menjadi salah satu kemajuan dan nilai tambah sendiri bagi pelanggan dalam memilih klinik kecantikan. Perusahaan selalu menampung kritik dan saran dari konsumen untuk terciptanya kenyamanan dan loyalitas konsumen. Selain itu loyalitas konsumen juga dilakukan dengan selalu mengecek dan mengevaluasi daya trafik per bulan, jika trafik mengalami penurunan Larissa Aesthetic Center cabang Jember langsung mengadakan promo untuk menstabilkan jumlah kunjungan.

\section{Pembahasan}

Berdasarkan hasil penelitian yang dijelaskan, strategi pemasaran yang dilakukan Larissa Aesthetic Center cabang Jember adalah strategi STP (Segmenting, Targeting, Positioning) yang bertujuan untuk memposisikan merek dibenak konsumen, sehingga merek tersebut memiliki keunggulan yang kompetitif yang berskesinambungan. Menurut Tjiptono (2007:211) bahwa sebuah produk memiliki keunggulan kompetitif jika produk tersebut menawarkan atribut-atribut yang bernilai penting di pelanggan. Larissa Aesthetic Center cabang Jember adalah klinik kecantikan yang mengusung konsep " Natural Ingredient With Technology" yaitu perawatan kulit, tubuh, dan rambut yang menggunakan bahan alami yang disinergikan dengan menggunakan teknologi modern. Untuk meningkatkan jumlah kunjungan Larissa Aesthetic Center cabang Jember melakukan segmentasi pasar berdasarkan kebutuhan dan keinginan konsumen. Proses segmenntasi pasar dilakukan melalui promosi baik secara online maupun offline. Secara online yaitu dengan memanfaatkan media sosial seperti Instagram, WhatsAap, facebook untuk dikenal wilayah sasaran. Sedangkan untuk offline dilakukan dengan penyebaran brosur, pamflet dan melakukan hubungan masyarakat seperti pengadaan Larissa Inclass di ibu PKK dan Dharmawanita, mengisi seminar tentang kesehatan kulit dan wajah di kampus negeri maupun swasta dan membuka open stand di CFD. Kegiatan tersebut untuk mengetahui kebutuhan, sikap perilaku konsumen dalam merespon pembelian dan produk yang ditawarkan. Kegiatan tersebut dilakukan sesuai teori yang dikemukakan Zeithmal dan Bitner (dalam Lupiyoadi dan Hamdani 2006:5) bahwa dalam pemasaran jasa kegiatan pemasaran perlu dilakukan, dari pemasaran yang dilakukan perusahaan akan mengetahui respon konsumen sehingga memudahkan perusahaan dalam mengembangkan pasar sasaran yang akan dituju.

Target pasar sasaran Larissa Aesthetic Center cabang Jember yang utama adalah mahasiswa, ibu-ibu muda dan karyawan swasta. Pemilihan target utama disesuaikan dengan lokasi yang bedekatan dengan lingkungan kampus. Target utama tersebut dianggap memiliki tingkat penjualan yang tinggi karena selain lokasi yang mudah dijangkau, harga yang ditawarkan masih mudah untuk dijangkau mahasiswa, ibu-ibu muda dan karyawan swasta. Hal ini sesuai teori dari Clancy dan Shulman (dalam Kasali, 2005:375) yang menyatakan bahwa kriteria memilih pasar sasaran yang optimal yaitu responsif dan juga potensi penjualan yang cukup luas. Dalam potensi penjualan yang cukup luas, perusahaaan melakukan strategi penetapan sasaran yang majemuk, dimana Larissa Aesthetic Center cabang Jember memandang konsumen sebagai sebuh pasar yang besar. Sehingga menciptakan beberapa jenis perawatan jasa dan produk yang berbeda-beda sehingga dapat memenuhi semua kebutuhan dan permasalahan konsumen secara luas.

Larissa Aesthetic Center cabang Jember menempatkan produknya dimata konsumen dengan menciptakan cipta merek atau citra perusahaan untuk menempati posisi persaingan yang baik. Citra merek tersebut sesuai dengan pendapat Rangkuti (2011:3) bahwa positioning adalah kegiatan menciptakan citra produk atau jasa sebaik mungkin sehingga mampu menempati posisi persaingan yang baik dan berbeda dalam pelanggan sasarannya. Citra merek yang ditanamkan di konsumen yaitu dengan memberitahukan kepada konsumen mengenai manfaat perawatan dan penggunaan produk. Adapun manfaat yang diperoleh yaitu perawatan jasa dan produk yang ditawarkan menggunakan bahan alami tentunya mana bagi kulit, menyehatkan dan hasil yang diberikan tidak muncul secara langsung tetapi melalui tahapan yang relatif cukup lama. Hal ini sesuai pendapat dari Zeithmal dan Bitner (dalam Lupiyoadi dan Hamdani 2006:5) menjelaskan bahwa jasa merupakan kegiatan ekonomi yang hasilnya tidak hanya produk fisik melainkan juga memberikan nilai tambah (misalnya 
kenyamanan, kesehatan konsumen, kesenangan, hiburan). Selain menetapkan citra merek, untuk menciptakan kesan yang baik dimata konsumen, yaitu perusahaan mengutamakan dalam segi kualitas dan pelayanan. Kualitas dan pelayanan yang dilakukan berpacu pada SOP yang ditetapkan perusahaan dan berpacu pada kebijakan mutu. Pelayanan yang diberikan kepada konsumen, Larissa Aesthetic Center cabang Jember selalu peduli dengan konsumen yang datang, peduli disini dalam artian peduli mengenai masalah yang dihadapi dan memberikan solusi terbaik tentang permasalahan yang dialami dengan penggunaan perawatan dan produk yang sudah disediakan. Konsep layanan yang diberikan mengedepankan etika berbicara, sopan santun, dan tingkah laku yang baik, hal itu sudah ditetapkan pada SOP. Larissa Aesthetic Center cabang Jember rutin melakukan komunikasi dengan para konsumen melalui media sosial seperti WhatsApp dan telefon untuk mengiatkan kedatangannya kembali di dua minggu sekali dan memberitahukan promo-promo yang sedang berlaku. Kegiatan yang dilakukan sesuai teori Zeithmal dan Batner (dalam Lupiyoadi dan Hamdani 2006:5) yaitu tentang pemasaran Interaktif. Larissa Aesthetic Center cabang Jember melakukan interaksi yang baik antara karyawan dengan pelanggan. Karyawan yang loyal akan memiliki motivasi tinggi untuk memberikan pelayanan yang terbaik kepada pelanggan dan menjadikan pelanggan tetap membina hubungan baik secara berkesinambungan dengan cara menjadikan pilihan perawatan di gerai Larissa Aesthetic Center cabang Jember.

\section{PENUTUP}

Berdasarkan hasil penelitian yang dilakukan, disimpulkan bahwa strategi segmenting dilakukan Larissa Aesthetic Center cabang Jember yaitu didasarkan pada segmentasi geografis dan demografis. Segmentasi geografis yaitu dalam pemasarannya menyebar di wilayah Tapal Kuda, meliputi : Jember, Bondowoso dan Lumajang. Segmentasi demografisnya meliputi: PNS, karyawan swasta, mahasiswa, ibu-ibu muda, usia 17-60 tahun, melayani perempuan dan laki-laki dan ditujukan untuk konsumen berpendapatan menengah dan menengah kebawah. Targeting pasar yang utama yaitu mahasiswa, ibu-ibu muda dan karyawan swasta. Strategi penetapan sasaran menggunakan strategi penetapan sasaran majemuk karena Larissa Aesthetic Center cabang Jember menganggap konsumen sebagai pasar yang besar sehingga menciptakan berbagai jenis perawatan dan produk yang dapat memenuhi kebutuhan konsumen secara luas. Positioning yang dilakukan yaitu dengan menempatkan citra merek dan slogan dibenak konsumen. Perawatan dan produk yang ditawarkan memiliki manfaat kesehatan, harga yang ditawarkan terdiri dari harga rendah, sedang, tinggi yang disesuaikan dengan kebutuhan dan keinginan konsumen.

Berdasarkan hasil penelitian, maka peneliti menyarankan sebaiknya Larissa Aesthetic Center cabang Jember meningkatkan dan memfokuskan segmentasi pasar untuk kalangan atas dan melakukan inovasi terhadap produk dan perawatan sehingga pelanggan semakin tertarik.

\section{DAFTAR PUSTAKA}

Kasali, R. 2005. Membidik Pasar Indonesia: Segmentasi, Targeting, dan Positioning. Cetakan Ketujuh. Jakarta: PT Gramedia Pustaka Utama.

Lupiyoadi, R., A. Hamdani.2006. Manajemen Pemasaran Jasa. Jakarta: Salemba Empat.

Rangkuti, F. 2011. Dongkrak Penjualan melalui Marketing Strategy \& Competitive Positioning. Gramedia

Tjiptono, F.,G. Chandra dan D. Adriana. 2007. Pemasaran Strategik: Yogyakarta: Andi 